Susan Petrilli*

\title{
Mother Sense, Language, and Logic
}

\section{On Victoria Welby, inventor of significs}

\begin{abstract}
Victoria Welby conceived a special approach to the theory of meaning, which she designated with the expression Significs. A central concept in her works is what she names mother sense, which she discusses in her correspondence with such figures as the English philosopher Ferdinand C. S. Schiller and the American pragmatist Charles Sanders Peirce, among others. Beyond her contribution to questions of the linguistic, semiotic, practicalethical, and pedagogical orders, the implications of her theory of meaning are particularly interesting for the "woman question" and for feminist discourse generally.
\end{abstract}

Keywords: feminist discourse; significs; theory of meaning; Victoria Welby; woman question

*Corresponding author, Susan Petrilli: Department of Lettere, Lingue, Arti, Italianistica, Culture comparate, The University of Bari Aldo Moro, Bari, Italy, email: susan.petrilli@gmail.com

\section{Victoria Welby and significs}

In this essay, we will address a characterizing aspect of Victoria Welby's intellectual work, precisely her theory of meaning, and focus on the original concept of mother sense. In fact, Victoria Welby (1837-1912) ideated a special approach to the theory of meaning, which she designated with the expression Significs. As underlined by this term, at the time a neologism, a large part of her research is dedicated to exploring the relation between signs and values, signs and sense, signs, sense, and significance, evidencing how meaning develops in signifying processes across different sign systems, languages, fields of discourse, and areas of experience without ever being constrained to any one of them, and how in the human social world these are always impregnated with values. On Welby's account, signs or words are all the more enhanced with meaning and value and at once are all the more rigorous the more they translate 
across the different domains of everyday life, scientific discourse, and spheres of the imagination (see Petrilli 2009).

In addition to "significance" and "interpretation," "translation" is another key concept in Welby's research on meaning and signifying processes at large. To understand the meaning of a word, it must be translated into another sign, whether verbal or nonverbal, into another word, whether from the same language or from different languages. And focusing on verbal language, Welby underlines just how important for the enhancement of human understanding figurative language is, giving particular attention to our use of metaphor. This leads her to thematize "critical linguistic consciousness" as a condition for the full development of our signifying resources and their expressive potential (see Welby 1983, 1985).

Another central concept in significs is what Welby names "mother sense." Mother sense is a central topic of discussion in her correspondence with such figures (among others) as the English philosopher and pragmatist Ferdinand C. S. Schiller (1864-1937) and the ideator of pragmatism, the American philosopher, mathematician, and scientist Charles Sanders Peirce (1839-1914), now also commonly recognized as the father-founder of modern semiotics. The present paper is dedicated to an exploration of this concept.

Welby exchanged and developed her ideas in her correspondence with significant figures from all walks of life and scientific domains. With reference to women, she was in dialogue with, among others: Mary Everest Boole (18321916), mathematician and educationist, wife of the renown mathematician George Boole, and author in her own right; Julia Wedgwood (1833-1913), a writer, historian and literary critic, and niece of Charles Darwin; Violet Paget (1856-1935), pseudonym Vernon Lee, a writer, committed feminist, and political activist; and lastly, Lucy Clifford (1846-1929), a novelist, journalist, and wife of mathematician and philosopher William Kingdom. Moreover, beyond real-life communication, Welby's ideas can be developed in "ideal dialogue" with authors she could never have crossed paths with in own her lifetime, as I have done myself, relating her ideas to those of the American philosopher Susanne Langer and to Genevieve Vaughan, ideator of the "gift economy" (see Petrilli 2015, 2016).

Welby's two main theoretical books are What Is Meaning? (1903, new edn. 1983) and Significs and Language (1911, new edn. 1985). Moreover, the youngest of her three children, Emmeline Mary Elizabeth (1867-1955), painter, sculptor, and writer, authored under her married name, Mrs. H. Cust, her mother's biography, Wanderers (Cust 1928), and edited her correspondence in two volumes: Echoes from Larger Life (1929) and Larger Dimensions (1930). A substantial collection of Welby's writings, published and unpublished, is now 
available in the volume Signifying and Understanding, edited by myself. This is followed (with respect to my publications in English) by my monograph, Victoria Welby and the Science of Signs. Significs, Semiotics, Philosophy of language (2015), as well as numerous book chapters and essays in journals.

\section{Sidelights}

After her marriage in 1861, not at all attracted to life at court, where she had served as Maid of Honour to Queen Victoria, Welby retreated to Denton Manor, Grantham, and soon thereafter began her research, with her husband's full support. Initially, her interest was directed toward theological issues, and in 1881 she published Links and Clues, which expressed her sympathy at that time with evangelical movements. This book presents a collection of reflections on the sacred scriptures and as such was considered unorthodox by authorities among the clergy of the time. Welby drew attention to the inadequacies of religious discourse, which she described as cast in outmoded linguistic forms. She was drawn into an examination of language and meaning, and found a pervasive linguistic confusion, which stemmed from a misconception of language as a system of fixed meanings, and which could be resolved only by the recognition that language must grow and change with human experience. She also made a serious study of science, believing that important scientific discoveries supplied the new experiences by which religious discourse could be transformed into something more meaningful.

Central to Welby's philosophy is her analysis of meaning into three components: sense - the organic response to environment (Hardwick 1977: xxii); meaning - the specific sense which a word is intended to convey; and significance - which encompasses the far-reaching consequence, implication, ultimate result, or outcome of some event or experience (Hardwick 1977). This triadic relationship relates closely to that established by Charles S. Peirce between "immediate interpretant," "dynamical interpretant," and "final interpretant” (Hardwick 1977: 109-11). Peirce read her 1903 book What Is Meaning? and reviewed it for The Nation alongside Bertrand Russell's Principles of Mathematics, to which he compared it in importance. A flourishing correspondence developed between Welby and Peirce, which influenced the development of the latter's thought system during the last decade of his intellectual work.

The interest Welby's work attracts today is illustrated by the publication in the 1980s and 1990s through to recent times of various editions of her work, as 
well as volumes of commentary on her thought system (see, for example, Colapietro, Nuessel \& Petrilli 2013; Petrilli 2009 and 2015). She contributed significantly to modern theories of signs, meaning, and interpretation, and introduced the term "significs" officially in an essay of 1896, "Sense, meaning and interpretation" (now available in Petrilli 2009: 430-449). Significs examines the interrelationship between sign, sense - in all its signifying implications - and value.

Besides numerous articles in newspapers, magazines, and scientific journals (notably The Spectator, The Expositor, The Fortnightly Review, The Open Court, Nature, Mind, The Monist, The Hibbert Journal, and The Journal of Philosophy, Psychology and Scientific Methods), Welby published a long list of privately printed essays, parables, aphorisms, and pamphlets on a large range of subjects in numerous spheres: science, religion, philosophy, mathematics, anthropology, education, and social areas. Alternatively to a series of pseudonyms or recourse to anonymity, she mainly published under her full name until the end of the 1880s, under the name of Hon. Lady Welby from 1890 to 1892, and as Victoria Welby from 1893 onwards.

As her research progressed, she promoted the study of significs, channeling the great breadth and variety of her interests into a significal perspective, which in turn fostered new developments. Shortly after the publication of two important essays - "Meaning and metaphor" in 1893 and "Sense, meaning and interpretation" in 1896 - the Welby prize for the best essay on significs was announced in the journal Mind in 1896 and in 1898 awarded to Ferdinand Tönnies for his essay "Philosophical terminology" (1899-1900).

Important moments of official recognition for significs are represented by the publication of the entries "Translation" (Welby 1902), "Significs" (coauthored with James M. Baldwin and George. F. Stout, 1902), and "Sensal” (with George F. Stout, 1902) in the Dictionary of Philosophy and Psychology in Three Volumes (1901-1905). However, the official recognition Welby had so tenaciously hoped for only came after approximately thirty years of "hard labor," with the publication of the entry "Significs" in the Encyclopaedia Britannica in 1911. Also, the Signific Movement in the Netherlands, which developed in two phases from 1917 to 1926 and from 1937 to 1956, originated from Welby's significs through the mediation of the Dutch psychiatrist, poet, and social reformer Frederik van Eeden (1860-1932).

From 1863 until her death in 1912, Welby was a friend and source of inspiration to leading personalities from the world of science and literature. She wrote regularly to over 450 correspondents from various countries including Great Britain, the United States of America, France, Italy, Germany, and the Netherlands. It was largely through such correspondence that she developed 
her theories. She began writing to politicians, representatives of the church, aristocrats, and intellectuals as early as 1870 and created an epistolary network which expanded rapidly from 1880 onwards, both locally and internationally. She used this network for her own enlightenment, as a sounding board for her own ideas, and as a means of circulating these ideas as much as those of others. Thanks also to her social position and court appointment as Maid of Honour to Queen Victoria, she counted friends and acquaintances among the aristocracy and government officials. Moreover, because of her interest in religious and theological questions, she corresponded with leading churchmen of her day and subsequently with eminent scientists, philosophers, and educationists, whom she welcomed into her home for open discussions. Beyond the names already mentioned, her correspondents included Michel Bréal, Bertrand Russell, Charles Kay Ogden, Herbert Spencer, Thomas Huxley, Benjamin Jowett, Francis Herbert Bradley, Henry Sidgwick, H. G. Wells, William James, and many, many more.

Nonetheless, in spite of the general awareness of the importance and originality of her thinking, Welby was largely forgotten after her death, though never totally, thanks to such exchanges. An important step toward recovering significs, the special approach she advocated to studies on language, meaning, and communication, was achieved, for example, with publication of her correspondence with Peirce in the volume of 1977, Semiotic and Significs, edited by Charles Hardwick. This was followed by a series of important editorial initiatives, among which re-publication of her books What Is Meaning? and Significs and Language, all of which has led to recognizing her today as the "founding mother," so to speak, of modern semiotics alongside Peirce, the "founding father" (Petrilli and Ponzio 2005).

In an attempt to avoid flattery, Welby, as mentioned above, either published anonymously or signed her work with pseudonyms, various combinations of initials, or simply as Victoria Welby. The only honor she valued was "that of being treated by workers as a serious worker" (Hardwick 1977: 13). Though she had no institutional affiliations, she was a member of the Aristotelian and Anthropological societies and was one of the original founders of the Sociological Society, between 1903 and 1904.

Welby was an open-minded intellectual in the Victorian era in spite of - or, perhaps, thanks to - her complete lack of a formal education, which led her to search for the conditions which made her theoretical work possible. She highlighted the importance for her intellectual development of her extensive travels as a child with her mother, which often took place in dramatic circumstances and ended with her mother's tragic death in the Syrian Desert, leaving Victoria all alone until help came from Beirut. On December 22, 1903, in 
a letter to Peirce, who fully recognized her genius (as testified by their correspondence), Welby suggested that her unconventional childhood

...accounts in some degree for my seeing things in a somewhat independent way. But the absence of any systematic mental training must be allowed for of course in any estimate of work done. ...I only allude to the unusual conditions of my childhood in order partly to account for my way of looking at and putting things: and my very point is that any value in it is impersonal. It suggests an ignored heritage, an unexplored mine. This I have tried to indicate in What Is Meaning? (Hardwick 1977: 13-14)

Welby died on March 29, 1912, at Duneaves, Mount Park, Harrow, and was buried in Grantham, Lincolnshire in England. Her scholarly estate is now mainly deposited in two archives: the Welby Collection in the York University archives (Downsview, Ontario, Canada) and the Lady Welby Library in the University of London Library. The latter includes approximately 1000 volumes from Victoria Welby's personal library and twenty-five pamphlet boxes containing pamphlets, reprints and newspaper cuttings, religious tracts, sermons, and published lectures by various authors. Four boxes without numbers contain duplicates of most of Welby's own publications. The main part of her scientific and literary production is in the York archives. Half of the collection consists of Welby's correspondence covering the years 1861-1912, and is still mostly unpublished. A large part of the remainder comprises notes, extracts, and commentaries on a variety of subjects - biology, education, ethics, eugenics, imagery, language and significance, logic and significance, matter and motion, numbers theory, philosophy and significance, significs, and time. There are also speeches, lessons, sermons by other authors, numerous unpublished essays and a collection of poems by Welby, diagrams and photographs, translations, proofs, copies of some of her publications, and newspaper cuttings.

Welby's writings are an important contribution to understanding problems connected with communication, expression, translation, and creativity from an interdisciplinary perspective. Moreover, beyond her contribution to questions of the specifically linguistic, semiotic, pragmatic-ethical and pedagogical orders, the implications of her theory of meaning for a better understanding of humanity, make it of special interest for present-day feminist discourse as well.

Welby's correspondence also reveals an attractive world in the feminine: a consistent community of women often in direct contact with each other as a consequence of their common connection to Welby herself, women thinkers variously involved in public life (among them, the aforementioned Mary Everest Boole, Julia Wedgwood, Vernon Lee, Lucy Clifford, and many more; Welby's relations on this account also involved figures like Queen Victoria, at once a 
critic and inspirer of feminist awakenings). Welby's ideas were sometimes accepted, sometimes challenged, giving rise to impassioned disputations, never indifference, in writings that travel through the worlds of philosophy, literature, and the sciences, at exquisite levels of poetic expressivity. These exchanges never fail to transpire with a profound sense of humanity.

At a time when the idea of female emancipation and feminist movements were still nascent, Welby and her writing companions were aware of the enormous discrepancy between a woman's capacity for critical reflection and social change, on the one hand, and opportunities to act in public and official worlds, on the other. With reference to modern Western feminist history, what has been retrospectively tagged "first-wave feminism," with its focus on legal issues and human rights, was in full swing during Welby's own lifetime. Though she was committed to what she called the "woman question" - for example, in her correspondence with Bertrand Russell (see her letter to Russell dated April 1, 1908, where she expresses her interest in his wife Dora for her political and social activities, in Petrilli 2009: 324) - Welby was critical all the same of what to her appeared to be exasperated, distorted, and consequently counterproductive approaches, such as when the struggle for human rights was reduced acritically to the struggle for "equality" with the male and imitation thereof. The suffragette movement presented an enormously important cultural development in Western society, and Welby was committed to women's rights, above all their right to health care, education, and a voice in the public sphere, but she did not always agree with the methods and discourse of mainstream militant feminists, especially when limited to imitating the very behavior they despised, contested, and wanted to modify. Welby's primary concern lay with humanity, with the quality of life for all, which necessarily implied improving the conditions for living and flourishing together. And working on communication and understanding, on developing the human capacity for linguistic consciousness and critique, she believed was an important step in that direction (see Petrilli 2009: 139-173)

In fact, she conceived a project for the emancipation and development of humanity overall, beginning with improvement of the expressive instruments at our disposal through adequate education. In this light, feminist movements that focused exclusively on the rights of women, on the "cult of effeminacy," seemed reductive to her. She warned militant feminists against the danger of "monkeyish imitation" of the male behavior they were contesting, while the "ruling female," in turn, would soon be imitated by man, thereby favoring the reign of power and violence over good and beauty. Welby appreciated feminist movements with their commitment to values and practices that she endorsed, but at the same time she insisted on the broader vision for the development of a 
new humanism and improvement of interpersonal relations beyond division among the sexes and subjectivities. Therefore, whilst acknowledging the importance of feminist movements, Welby was eager to promote the principles of interrelatedness and mutual understanding among unique human beings in the interplay between totality and difference against the tendency to build barriers or exasperate identities and separations (Petrilli 2009: 590-597).

\section{Mother sense and its implications}

Welby formulated her original concept of "mother sense" in a series of unpublished manuscripts written at the beginning of the twentieth century. Subsequently, she replaced the term with the expressions "primal sense" and its variant "primary sense," and also proposed further synonyms such as "original sense," "native sense," "racial sense," "race motherhood," and "matrical sense" (from "matrix"). The expression "mother sense" was coined around 1890 and was not intended as a gender specification. However, as much as she preferred the expression "mother sense," she introduced alternatives like those just listed, in particular "primal sense" and "primary sense," to avoid misunderstanding and restrictions of the gender order. The concept of mother sense as thematized by Welby plays a central role in signifying and interpretative processes and in modeling worldviews. The manuscripts referred to in this paper are now included in the volume Signifying and Understanding. Reading Victoria Welby and the Signific Movement in the Netherlands (see Petrilli 2009: Ch. 6; see also Petrilli 2015).

Welby distinguished between "sense" or "mother sense," on the one the hand, and "intellect" or "father reason," on the other. These are transgender specifications with which she wished to indicate a general difference between two predominant modalities in the generation of sense which cut across the barriers of sexual difference: mother sense is not exclusive to women, just as "father sense," or "father reason" is not exclusive to men. Separable only by abstraction, on a theoretical level, they in fact operate together on a pragmaticoperative level in sense-producing practices. Mother sense alludes to a form of sense that is shared by the whole of humanity, that is specific to it, that characterizes it, a generating source of sense common to humankind, that concerns us all, and that is also evoked through such concepts as "intuition," "judgment," and "wisdom." Its rudimental forms are traceable in what Welby calls "in-sense" or "pre-sense." 
This original or primal dimension of sense, "mother sense," interweaves with rational, intellectual life in a relation of dialectic interdependency and reciprocal enrichment. Knowledge and expression, whether in specialized or everyday spheres, in scientific or nonscientific spheres, is grounded in "mother sense." "Mother sense" includes "father sense" or "father reason," "intellect" (even if latently), while the converse is not always true. Logic, the intellect, father reason must be grounded in the broader and generative dimension of sense, the original level, the primal level, mother sense, racial sense, the "matrix," in a relation of dialectic interdependency and mutual empowering, so that mother sense and father reason should be recovered in their original condition of dialectic and dialogic interrelation, on both the phylogenetic and ontogenetic level.

The logical capacity must never be separated from mother sense. On the contrary, for full development of the human capacity in terms of the intellect, of reasoning, critique, value, and significance, the relation between mother sense and rational life must be one of mutual empowering. With her significs Welby aimed to recover this relation. And though common to humanity, this mother sense, this primal sense, is particularly alive in the woman, its main guardian and disseminator for socio-cultural reasons, and not through any form of natural necessity which renders her especially responsible for the recovery of ancient wisdom and development of the capacity for creativity and critique, for planning and prevision.

In a paper dated April 15, 1907, "Primal Sense and Significs” (originally entitled "Mother Sense and Significs," now in Petrilli 2009: 704-706), mother sense is described as the generating source of sense and meaning, of the interpretative and inventive capacity, of the capacity for solving problems, and for discernment. "Mother sense" is the matter of "immediate, unconscious, and interpretative intuition," from an evolutionary point of view, it constitutes the "subsequent phase, on the level of value, to animal instinct." Therefore, it is at once "primordial and universal" and is traceable to varying degrees throughout the whole course of the evolution of humanity. Mother sense concerns the real insofar as it is part of human practice and the ideal insofar as it is the condition by virtue of which humanity may aspire to continuity, ongoing perfection and progress (Welby in Petrilli 2009: 704).

However in the history of civilization "mother sense" has often been artificially suppressed and the mother figure overpowered by the violence of her sons; indeed, she is often abused and violated by her own creation, the male, in spite of her social roles and responsibilities. In fact, in Welby's description, the history of the human race is also the history of continual deviations in development, of the loss of mother sense and with it the loss of the sense of 
discernment and of the capacity for critique and responsible awareness, the most serious deviation of all. Such a loss, for example, induces one to be satisfied with the existent as it is. On the contrary, what is needed to the end of developing and perfecting the human race is the condition of eternal dissatisfaction, as Welby says (see below).

Mother sense denotes a broad capacity for knowledge through feeling and perception. It is specific to human beings, and though not exclusive to women, traditionally they are its main custodians for sociocultural reasons, as anticipated above. Father reason or father sense is associated with the intellect and implies the acquisition of knowledge through assertion, rational argumentation, the capacity for generalization, and experimentation in science and logic. Though commonly associated with men, it is not at all exclusive to them. "Mother sense" should not be confused with "female" or "feminine," with "woman." The masculine (the intellect) and the feminine (sense, mother sense), from which the intellect derives, coexist in each single individual, at least potentially. According to Welby, motherhood implies the masculine in a way that "fatherhood" does not involve the feminine. Consequently, the term "motherhood" does not necessarily refer to physiological maternity, though this no doubt is one of its possible manifestations.

Mother sense may be understood in the double sense of sapio and scio (with reference to the Latin sapere). Sense already senses and savors what the intellect must work toward. In other words, what the intellect must strive to discover, the body somehow already knows. For its full development, the intellect must be nourished by mother sense. Mother sense subtends the capacity for argumentation and criticism as its foundation and very condition of possibility.

In the light of evolutionary theories prevailing at the time, of which she does not fail to be critical, Welby rereads the Bible story and places woman at the center of creation. In fact, it is the woman who represents the power of reproduction and the principle of continuity, and as such she best symbolizes the human race, while men introduce the principle of variation. The human being, whether male or female, is not fully human if the maternal element or "mother sense" is lacking, or denied. In an unpublished paper entitled "Motherhood of Man," Welby specifies that the woman in the mother is passive and anabolic, while the fe-male in her is catabolic, an active source of nourishment.

As a mother, the woman incorporates man in a relation where the male and female components in her are actively interrelated: "man is the whole term; it means human," where "man" may be understood in the sense of the original Greek term anthropos. In such a framework, the male and female principia are 
not divided and separate elements, but rather are interrelated in a spiral type of progression characterized by openness and continuity rather than by circularity and uncreative repetition.

What the Russian philosopher of language Mikhail Bakhtin (1895-1975) conceptualized as the dialogic relation among differences can be extended to Welby and her concept of dialogic complementarity rather than of separation among sexual differences, based on mother sense.

Sense is also described by Welby as "instinctively religious," where "religious" is understood as "feeling awareness of the solar relation." Her reference is to a universal sense of dependence upon something greater, a sense of implication in a vaster world, a more elevated world, a world made of other origins and other relations beyond the human, beyond the merely planetary. As she clarifies in her papers, mother sense does not imply anthropomorphism, but far more extensively organicomorphism, on the one hand, and cosmomorphism, on the other. On this account, too, Welby's approach can be associated again with Peirce's, in particular his synechism.

Mother sense is the condition for the generation of infinite new worlds in a potentially unending variety of possible articulations and signifying processes, of worldviews. It is both analytical and synthetic. We have anticipated that it determines the capacity for knowing in far-reaching and creative ways through sentiment, perception, intuition. As such, in terms of inferential procedure, it allows for cognitive leaps, for the ability to progress in both quantitative and qualitative terms, which involves the capacity to change attitude and perspective: "Calculation gives useful results but without sense and judgement of quality it can only give the description of the fact" (Petrilli and Ponzio 2005: 8.2). Thanks to mother sense, the idea is intuited before it is possessed or before it possesses us, to evoke Charles S. Peirce's (1839-1914) terminology. Peirce speaks of "agapic" or "sympathetic comprehension and recognition" (see below), which can be associated to Bakhtin's concept of "answering comprehension" or "responsive understanding."

Welby's significal approach to the life of signs recovers the relation of responsive understanding among signs, which is only possible by keeping account of the relation between mother sense and father reason, and by embedding logical procedure in this relation. Such a relation is the necessary condition for the full development of critical sense, of the maximum value, meaning, and purport of all experience.

The implications of the concept of mother sense become clearer in light of modeling systems theory (Danesi and Sebeok 2000), with special reference to the concept of "primary modeling" as thematized by Thomas A. Sebeok (19202001; see Sebeok 1986, 1994, 2001; Petrilli 2012: 7-10, 150-152). The "primary 
modeling system" is described as an innate modeling device present in all living species. On the basis of this innate simulatory modeling capacity, all species simulate their worlds in their own species-specific ways. Primary modeling in anthroposemiosis is thematized as a necessary condition for the acquisition and generation of knowledge, for communication through the various sign systems forming human behavior, both verbal and nonverbal. Verbal language arises specifically as a response to communication needs in the course of evolution, though it remains rooted in the primary modeling device and itself takes on a secondary modeling function in addition to its communicative function.

Primary modeling as we are describing it is already present in the mute hominid and acts as the departure point for a new course in evolution leading to the rise of Homo sapiens sapiens (see Posner, Robering, and Sebeok 1997-2004, Art. 18, § 5-6; Sebeok 1986; Sebeok and Danesi 2000). Given that the primary modeling system specific to humans is a syntactical device, Sebeok also denominated it "language," distinct from "speech" and antecedent to it (Petrilli and Ponzio 2005: 8.1). Because of the syntactical component, another term proposed for primary modeling in the human world is "writing," that is, writing ante litteram, writing that precedes the letter (Ibid.: Ch. 9).

"Secondary modeling systems," in part now redefined as "tertiary modeling systems," may be described in terms of derivative signifying behavior characteristic of human culture, including "speech." The latter arises specifically for communication and intellectual work generally and is generated by primal matter, as one of its possible expressions and manifestations. Secondary and tertiary modeling systems are grounded in the primary modeling system and, like primary modeling, are also endowed with a capacity for creativity and inventiveness at the highest degrees.

As articulate, signified, already configured realities, human derivative worlds are at once the projection, interpretation, and development of mother sense, on the one hand, and its reduction and simplification, on the other. Similarly to language as theorized by Sebeok (revisiting the Moscow-Tartu school of semiotics), mother sense is a necessary condition for the evolution of the human race both ontologically and phylogenetically and, therefore, for the full development of historical and social practices.

The concept of mother sense can also be associated with Peirce when he maintains (in a note to his 1878 essay, "How to Make Our Ideas Clear") that the "great principle of logic is self-surrender." Self-surrender is the rule itself that governs one's relation to the other; it means putting oneself at the other's disposal, to listen to the other. As Peirce says, self-surrender does not imply that "self is to lay low for the sake of an ultimate triumph. It may turn out so; but that must not be the governing purpose" ( $C P$ 5.402, note 2). Mother sense can 
also be associated to Peirce's "principle of continuity," according to which "all is fluid" and "every point directly partakes the being of every other." Peirce also maintains that "individualism and falsity are one and the same":

We know that man is not whole as long as he is single, that he is essentially a possible member of society. Especially one man's experience is nothing, if it stands alone. If he sees what others cannot, we call it hallucination. It is not "my" experience, but "our" experience that has to be thought of; and this "us" has indefinite possibilities. (CP 5.402, note 2)

In a letter to Peirce of January 21, 1909, Welby agrees with his observation that logic is the "ethics of the intellect"; this is in line with her "ethics of criticism." Scientific rigor in reasoning, to be worthy of such a description, must rise from what we might name, evoking Peirce, agapastic logical procedures, from "primal sense," and, therefore, from the courage of admitting to the structural necessity of imprecision, instability, and crisis for the evolution of sign, subject, and consciousness (see Welby to Peirce January 21, 1909, in Hardwick 1977: 91).

In a letter to Welby of May 7, 1904, Peirce observes that "reason blunders so very frequently that in practical matters we must rely on instinct \& subconscious operations of the mind, as much as possible, in order to succeed. Thus, in my logic there is a great gulf between the methods proper to practical and to theoretical question, in which latter I will not allow instinct, 'natural' reason, etc. to have any voice at all" (in Hardwick 1977: 19-20; see also CP 1.616-1.677). Welby thematizes a dialectical relation between distinction (which is never separation or division) and unity, and responds to Peirce in a letter of June 29, 1904, commenting that

in my logic (if you will allow me any!) I see no great gulf, but only a useful distinction between methods proper to practical and theoretical questions. So then 'Never confound, and never divide' is in these matters my motto. And I had gathered, I hope not quite mistakenly, that you also saw the disastrous result of digging gulfs to separate when it was really a question of distinction, - as sharp and clear as you like. (Welby in Hardwick 1977: 21)

Like Peirce, Welby too underlined sociality as an essential dimension of the human condition. She thematized the need to develop a "social conscience," relating mother sense to the capacity for a radically critical sense of the social. Here, a critical social conscience also implies the capacity to transcend the constraints of convention and the effort to benefit what can be designated as a concrete abstraction, that is, future generations. 
Similarly to Peirce, who worked on the concept of creative love or agapasm and maintained that evolutionary development engendered by the logic of love derives from love orientated toward something concrete, Welby too, though independently from Peirce, described the logic of mother sense as orientated toward one's concrete neighbor, that is, one's neighbor understood in terms of affinity or similarity beyond distance in space and time. And while theorizing the concept of "concrete neighbor," Welby criticized the threat of "vague and void abstractions" as exemplified by bad use of the term "future."

In terms of logic and argumentation, the "intellect" or "father reason" may be associated with induction and deduction, that is, with inferential processes dominated by the logic of identity. By contrast, mother sense is associated with the capacity for abduction, which is oriented by the logic of otherness, creativity, dialogism, freedom, and desire, in the last analysis by creative love, agape to recall Peirce. That abductive inferential processes are oriented by values connected with the logic of otherness means to say that they are called forth by the other, in a relation of "proximity," to use a concept introduced by the French philosopher Emmanuel Levinas (1906-1995), which means to say in a relation where the other evades the comprehensive totality and its identity logic.

With reference to Peirce's classification of signs into symbol, index, and icon, while father sense is associated with the symbolic and indexical dimension of semiosis, mother sense is characterized by iconicity. Again, this means to say that it alludes to the creative and generative forces of sense, to the capacity for identifying both analogical and homological relations, the capacity to associate things that may seem distant from each other, but which in reality are attracted to each other, as in case of the iconic relation among signs, precisely.

\section{More insights}

In a letter to Welby of October 2, 1907, Ferdinand C. S. Schiller (1864-1937) suggests that she replace "mother sense" with the expression "common sense" to avoid oversimplified interpretations of her position. He believed that the expression "mother sense" could be easily misunderstood as intending to exclude the male sex. In Schiller's own words:

But why should you not identify your Mother sense with Commonsense and call it (mainly) that? It is what at bottom you mean-the wisdom of the "tout le monde" which is wiser than the sages, which pervades society and its history and is rarely formulated and never adequately expressed in set logical terms. It is truly "common" in that it can be fathered 
upon no one, and in that it is at the basis of our "common" life in society; it is also "mother," in that the logical acumen grows out of it. I am also willing to believe that women in general, when one gets beneath the surface of their frivolities and follies, have retained a closer contact with this force and that e.g. the "maternal instinct" will (despite all appearances to the contrary) triumph over "race-suicide" temptations, if only women are given a free hand in the regulation of things. So you would have ample reason for calling this "common-sense" a "mother sense," but the more you emphasised the former phrase the more intelligible you would become to the mere male! (Schiller to Welby October 2, 1907, now in Petrilli 2009: 632)

With Schiller, to analyze intuition is not so much to deny logic as to reformulate it, which in fact is very much in line with Welby's own view. In any case, as much as "mother sense" may converge with "common sense," such that under certain aspects this statement may seem a truism, Welby chose to avoid the term "common" because of its negative and oversimplifying associations.

However, she did agree that the term "mother" risked being interpreted reductively, as when it is simply identified with the biological dimension of life. Far more broadly, "mother sense" or "primal sense" refers to primal signifying matter, primordial and pre-sexual, antecedent to division among the sexes, where the female and the male principia are united. As anticipated above, with the concept of "mother sense" or "primal sense" Welby invites us to reflect on the maternal component in human beings generally and on the logical capacity insofar as it is a derivative of this primordial device. In her own words from a text of 30 June 1908:

My own transition (as a matter of precaution) from "mother" to "primal" (with, as variant, "primary") sense, is an illustration of the difficulties created by our neglect of Significs. For it ought to be understood at once, that in such a context as mine I cannot possibly mean by Mother sense, mainly, still less only, the shrewd or practical insight of the typical "mother" in the actual or organic sense. Naturally I mean a primordial, inceptive, inborn, need-fertilised, danger-prompted, interest-stimulated, Sense. "Mother" is indeed or ought to be, the wide and general, "father" the specialised, term. The pre-sexual organism was the maternal, and included the paternal element. We already recognise this in our philosophical and scientific use of the term matrix. We never, in this connection, use the term patrix; and we are quite right. The "mother" is enabled by stimulus to conceive, develop, nourish new life. (Welby 1908, in Petrilli 2009: 710)

With Welby, we have claimed that mother sense is a necessary condition for the development of the human race, from both the ontological and phylogenetic perspective, and for the historical practices of socialization. After introducing this expression around 1890, she only focused on it systematically from 1904 onward, initially as part of her contribution to the public debate on eugenics in 
the (important but naïve) conception of Francis Galton. In a paper read on May 16, 1904, at a meeting organized by the Sociological Society, Welby explains that eugenics, a new science, "studies the influences that improve and develop to a maximum the innate qualities of the human race" (now in Petrilli 2009). She was the only woman to take part in the discussion. However, as an aside with respect to our concerns in this paper, we will point out that, contrary to anything Welby could have ever imagined, we know that eugenics was subsequently translated into the ideology of the perfect race with the crimes against humanity that ensued.

In her paper, Welby reflects upon the woman's responsibilities in the social sphere as a consequence of the racial sense she is endowed with and is held to transmit to future generations. As anticipated above, "mother sense," "racial sense" or "racial motherhood," evoked through a series of stereotypes such as "intuition," "judgment," "wisdom," is described as a form of sense common to men and women, "a heritage common to humanity," though mainly handed down from a historical-social perspective to oncoming generations by the woman through the social practices she is called to carry out daily - for example, as mother and wife, caring and nurturing, caring for one's offspring and the future generations they represent. Such practices are oriented by the logic of self-giving, by responsiveness to the other, by care for the other.

Welby set herself the task of illustrating "the specialized mental activities of women distinct from men." However, "mother sense" or "racial sense," whose rudimental forms, as Welby says, are traceable in what she calls "in-sense" or "pre-sense," is largely suppressed throughout the history of civilization. All the same, given that in historical-social terms it is especially the woman who is responsive to mother sense, racial sense, the sense of racial motherhood, Welby evidenced the responsibility of women who should be committed to recovering ancient wisdom and with it the human capacity for critique and creativity.

In addition to indicating the social practices and functions carried out by women daily, Welby also underlined the crucially important role played by women in the development of speech, in the acquisition of verbal language, consequently in sign and social activity overall, and therefore, we might add, in the construction of the "symbolic order," or in our own terminology, the "semiotic order." Paradoxically, however, womankind has constantly been inhibited when it comes to a question of public roles. And, as hinted above, Welby saw in this historical fact one of the causes for continuous deviations in the social development of the human race, for loss in the capacity for discernment and critique, being the most serious consequence of all, given that it induces one to be satisfied with the world as-it-is. On the contrary, what is needed to the end of developing and perfecting the human race is a condition of 
eternal dissatisfaction: "We are all, men and women, apt to be satisfied now... with things as they are. But that is just what we all came into the world to be dissatisfied with" (Welby 1905, now in Petrilli 2009: 727).

With the concept of mother sense, racial motherhood, Welby expresses the need to recover the creative and critical capacity of the human intellect, the propensity for creative interpretation, translation, transformation, prediction, and innovation. Mother sense is connected with the capacity for critical social consciousness beyond the conventions of any order whatsoever such as the social, moral, and religious, for the sake of future generations. As she stated in an undated reply to Schiller's letter of October 2, 1907:

(A) Well, the mother sense never "sets its heart" on any "pet hypothesis": if it had done this in the original days of its reign, you and I would never have been here. The race would have been snuffed out. No: it takes one hypothesis after the other, treating the one it "cares" for with a more uncompromising scrutiny and severity than the others. The very life of its owner and her children once hung upon this instinct of suspicion and of test. It is sheer mother sense - instinct of intellectual danger - which in you, as in Dewey, Peirce and James, calls out the pragmatic reaction! It is the direct descendent of the keen awareness of the signs of primitive danger to the babes of the pair or the tribe, left in relatively weak hands. But let the pragmatists beware of exchanging one fallacy or one overworked method for another perhaps its opposite.

(B) Yes, all half-words (and some spuriously used whole ones) are handicaps. They settle your involuntary dualisms from the first. As to the "majority of women," the dominant Man with his imperious intellect has for uncounted ages stamped down their original gift: all their activities beyond the nursery (and, alas, there also now) are masculinised: language, originally the woman's as custodian of the camp, creator of its industries and first trainer of the next generation, is now wholly "male": the whole social order is laid down, prescribed for the woman on masculine lines only. Who ever, for instance, thought of consulting her about changes in marriage law? Well, it would after all have been useless: you have crushed out all but her illogical prejudices and her emotional insistencies, which urge her to set her heart on pet hypotheses or to cling to doctrinal mummies as though they were living. These are really the last refuge of a balked prerogative of mind. Frivolities and follies! What else is left to one for whom "strongminded" has become an epithet of dislike and contempt? And when the suppressed energies of the race do, in spite of all, "spurt up" in us women, what can their fruit be, as things are, but abortive and defective? The present mode of "College" or "technical" training can at best but make the woman a second- or third-rate Man: she further loses thereby what little she has of the racial gifts-her natural and complementary powers of interpretation and problem-solution, of suggestion and correction. Again look at her inventive complexities, e.g. of weaving.

Woman was of course the original weaver. Look at her logic and mathematics of the knitting-pin, the hook, the shuttle, the needle. Look at old lace and embroidery. I myself have "invented" elaborate figures produced by a mere hook, and "stitches" by a mere 
needle. No man has ever, apparently, seen the significance of woman's ingenuities here and applied them to his inventions, or in his training of students. Practically only the sailor and the fisherman understand even knot- and net-work.

That the Mother sense is "common" seems to me a truism. Of course it is common. Only, the word common is used in several senses. In one it means despicable and is coupled with "unclean." On another side, Loeb's tropisms are common! And my Originating, Birthgiving, Reproductive, Interpretative-my Mother sense, is common to the whole range of life and extends beyond it and beneath it. (Welby 1907, in Petrilli 2009: 634)

Welby does not refuse dominant logic, the established symbolic order whose incalculable value she recognizes, but in the spirit of significs, she appeals for constructive criticism with respect to our use of logic itself, of cognitive instruments and interpretative models. In "Primal Sense and Significs," she describes "primal sense" as the "mother of senses"; it indicates a comprehensive and homogeneous faculty, a psychic-physical power of response and adjustment, an organic form of knowledge necessary to the survival of the human race. Mother sense is the generating source of the rationalizing intellect and the task of significs is

not only to criticise, but also to reason out and construct from the données of Primal Sense, its warnings, its insights and farsights, its revelations, its swift readings of worth, its penetrative recognition of reality. It is just here, then, that the place and work of Significs is to be found, as the necessary link - rather, the medium of interpretative communication - between the constant "givings" of Mother sense and the constant "constructions" (in all senses) of the intellect. (Welby 1907, in Petrilli 2009: 704)

Recovery of the connection between the rational dimension of the intellect and primal sense is a sure way to enhance the value, meaning, and import of all experience. In fact, as stated in the citation above, one of the main tasks assigned to significs is to recover the relation of mutual interpretability and dynamical interdependency between the constant données of mother sense, on the one hand, and the constant constructions of the intellect on the other. Primal sense provides us with the material of "immediate awareness, conscious and interpretative"; from an evolutionary viewpoint, it represents "a further stage in value, of the animal's instinct." Therefore primal sense is together "primordial and universal" and is present at all stages of human development in varying degrees; as such, it is the condition for the development of significance. To evoke Levinas (1974) once again, we could claim that mother sense corresponds to significance before and after signification.

By reconnecting primal sense and rational behavior, it is possible to recover the sense of symbolic pertinence active in the child, whose propensity for 
investigation Welby goes so far as to describe as a cognitive model for the adult. Critical work is inevitably mediated by language, here understood in the strict sense of verbal language. Welby's critique of language is central to significs. Language and consciousness are inseparable and together are grounded in primal sense. Welby underlines the importance of developing a "critical linguistic consciousness" and of using language in such a way as to enhance the exquisitely human capacity for "answering comprehension," for understanding that is dialogical and responsive, to say it with Bakhtin (1981, 1986, 1990).

Under certain aspects, Peirce and Welby adopt approaches to the problem of mind and subjectivity that, though elaborated independently of each other, are similar. This emerges, for example, from their observations on the so-called "obscure part" of the mind, or on behavior governed by intuition, sense, "mother wit" - the expression is Peirce's (on the concept of wit and ingenuity in Peirce and in Welby, see Colapietro 2013). Consider the following excerpt from Peirce's "Logic and Spiritualism” in the light of Welby's work:

Swarming facts positively leave no doubt that vivid consciousness, subject to attention and control, embraces at any one moment a mere scrap of our psychical activity. Without attempting accuracy of statement demanding long explanations, and irrelevant to present purposes, three propositions may be laid down. (1) The obscure part of the mind is the principal part. (2) It acts with far more unerring accuracy than the rest. (3) It is almost infinitely more delicate in its sensibilities. Man's fully conscious inferences have no quantitative delicacy, except where they repose on arithmetic and measurement, which are mechanical processes; and they are almost as likely as not to be downright blunders. But unconscious or semi-conscious irreflective judgments of mother wit, like instinctive inferences of brutes, answer questions of "how much" with curious accuracy; and are seldom totally mistaken. (CP 6.569)

To Peirce's observation that logic is the "ethics of the intellect," Welby responds with her conception of primal sense, which she presents as the way to the ethical dimension of signifying processes beyond the strictly gnoseological. Reflecting on her preference for the term "significs" rather than "semeiotic" as the name for her theory of sign and meaning, she makes the following considerations:

Of course I am fully aware that Semeiotic may be considered the scientific and philosophic form of that study which I hope may become generally known as Significs. Though I don't think you need despair of the acceptance of your own more abstract, logically abstruse, philosophically profound conception of Semeiotic. Of course I assent to your definition of a logical inference, and agree that Logic is in fact an application of orality in the largest and highest sense of the word. That is entirely consonant with the witness of Primal Sense. 
Alas, there is no word (except religion) more dangerously taken in vain than morality. (Hardwick 1977: 91)

We know that one of the main goals of the project for significs is to fully recover the connection between logic and primal sense, the matrix of sense, in a relation of reciprocal interdependency and enhancement. This implies recovering mother sense, common sense in all its signifying valency, from the instinctive-biological level to the level of significance. By recovering the relation between logic and sense, sense and value, sign and sense, significs furthers the quest for the properly human and theorizes the possibility of extending logic beyond its strictly gnoseological boundaries.

Significs reconnects logic to bio-logic, on the one hand, and to the ethical and aesthetic spheres, on the other, prefiguring what today we propose to describe as the "semioethic" turn in studies on sign and meaning (see Petrilli 2014). In fact, opening toward the other, to the capacity for involvement with the other, for responsiveness to the other, points to the importance of the ethical dimension of human signifying practices, to the relation between signs and values before and beyond the strictly gnoseological order.

With specific reference to subjectivity, like Peirce, Welby too describes human beings as a community of parts that are distinct but not separate. Far from excluding each other, these parts, or selves, are reciprocally dependent on each other; they are regulated by the logic of dialogic otherness and of nonindifference. Such an approach excludes the possibility of undifferentiated confusion and homologation among differences and specificities, as in the case of the monological and monolingual self. To confound is to sacrifice distinction. Nor does interrelation and interconnectedness mean sacrificing uniqueness, singularity, just as uniqueness does not call for sacrificing the condition of dialogical interrelatedness, intercorporeitiy, contact, and communication.

In her writings on subjectivity, Welby distinguishes between the "self" and the "I" or "Ident," introducing yet another neologism (see her paper "I and Self," June 1907, now in Petrilli 2009a: 647-648), where the I represents an excess with respect to the sum of its parts. The I is not the "individual" considered as separate from the other, but rather the "unique." Welby's conception of "uniqueness" (which has no connection with the monadic separatism of Max Stirner's conception of the unique and the singular) may be related to what Levinas thematizes as "nonrelative otherness" or "absolute otherness."

As Peirce says in his 1892 essay entitled "The Law of Mind," the type of evolution foreseen by synechism, the principle of continuity, is evolution through the agency of love, whose prime characteristic consists in recognizing 
the germs of loveliness in the hateful and making it lovable (CP 6.287-6.289). Peirce polemically contrasts the "Gospel of Christ," according to which progress is achieved through a relation of sympathy among neighbors, with the "Gospel of greed," which reflects the dominant ideology of his day and encourages the individual to assert one's own rights and interests, one's own individuality or egotistic identity, over the other (CP 6.294).

A parallel may be drawn between Peirce's critique of the supremacy of the individual and Welby's in her analysis of the dynamics between I and self, where she criticizes the self's tendency to transform "selfness" into "selfishness" and "selfism." According to Peirce, Darwin's The Origin of Species (1859), with his concepts of natural selection, survival of the fittest, struggle for existence, is a significant example of how this conception of the individual is translated from political economy to the life sciences, from economic development to the development of the living organism. Peirce himself chose the agapastic theory of evolution, and in fact he considered his own strong attraction to this doctrine as possible proof of its validity (CP 6.295). On Peirce's account, love is directed to the concrete, and not to abstractions; it is directed toward one's neighbor, not necessarily in a spatial sense, locally, but in the sense of affinity, a person "we live near... in life and feeling." Love is a driving force in logical procedures dominated by abduction, iconicity, and creativity. In accordance with his interpretation of St. John, the development of mind understood in an extended sense occurs largely through the power of love.

Recalling the writer Henry James, Peirce distinguishes between self-love, which is directed at another insofar as that other is identical to self, and creative love, which is directed at what is completely different, even "hostile and negative" with respect to oneself; this latter type of love is directed at the other insofar as this other is absolutely other, as Levinas would say.

On this basis, one might propose a typology of love measured in terms of otherness on a scale that moves from high degrees of identity to high degrees of alterity. But truly creative love, as both Welby and Peirce argue, is love regulated by the logic of otherness, love for the other, directed to the other insofar as that other is absolutely other. The logic of otherness is an agapastic logic. And absolute, nonrelative otherness, iconicity, love, dialogism, and abduction together constitute the generative nucleus of signs and senses as they translate across worlds, whether real, possible, or imaginary.

Welby's concept of mother sense can be read in the light of our project for semioethics and the goal of accounting for the "reason of things" (Petrilli and Ponzio 2003, 2010, 2014). However, as Welby's significs no less than Peirce's semiotics teach us, the reason of things cannot be separated from the capacity for reasonableness, and reasonableness is other orientated. The issue at stake is 
the following: given that social reproduction today constitutes a threat to life, human beings must at their very earliest transform from rational animals into reasonable animals, and on this account, we believe that an understanding of the concept of mother sense can make a contribution that is no less than decisive.

Note: The English philosopher Victoria Lady Welby (1837-1912) was the youngest of three children of Charles James Stuart-Wortley (1802-1844) and his wife, Lady Emmeline Charlotte Elizabeth Stuart-Wortley, née Manners (18061855), poet and traveler. James Archibald Stuart-Wortley (1776-1845) was her grandfather. As a child, Victoria Welby had little formal education, aside from some private tuition, which was not at all exceptional in her day, particularly with regard to female children (see her letter to Charles S. Peirce, dated December 22, 1903, in Hardwick 1977, now in Petrilli 2009: 12). From 1848 to 1855, she travelled extensively with her mother in the United States, Canada, Mexico, Spain, Morocco, Turkey, Palestine, Syria, and to many other countries. Her travel diary was published in 1852. After her mother's tragic death in the Syrian Desert, she lived with a succession of relatives before being taken in by her godmother, the Duchess of Kent, mother of Queen Victoria. In 1861, she was appointed Maid of Honour to Queen Victoria; she spent almost two years at the royal court before her marriage in London, on July 4, 1863, to Sir William Earle Welby-Gregory. During the first years of her marriage, Victoria Welby founded the Royal School of Art Needlework.

\section{References}

Bakhtin, Mikhail M. 1981. The Dialogic Imagination: Four Essays. Austin: University of Texas Press.

Bakhtin, Mikhail M. 1986. Speech Genres \& Other Late Essays, Caryl Emerson and Michael Holquist (eds.), Vern W. McGee (trans.). Austin: Austin University of Texas Press.

Bakhtin, Mikhail M. 1990. Art and Answerability. Early Philosophical Essays by M. M. Bakhtin, Michael Holquist \& Vadim Liapunov (eds.), Vadim Liapunov (trans. \& notes), Kenneth Brostrom (supplementary trans.). Austin: Austin University of Texas Press.

Colapietro, Vincent. 2013. The life of significance. Cultivating ingenuity no less than signs. In: Vincent Colapietro, Frank Nuessel \& Susan Petrilli (eds.), On and Beyond Significs: Centennial Issue for Victoria Lady Welby (1837-1912), Semiotica. Journal of the International Association for Semiotic Studies 196, 35-56.

Colapietro, Vincent, Frank Nuessel, \& Susan Petrilli (eds.). 2013. On and Beyond Significs: Centennial Issue for Victoria Lady Welby (1837-1912), Semiotica. Journal of the 
International Association for Semiotic Studies, 196, 1-4. Special Issue, Frank Nuessel \& Vincent Colapietro (Intro.), 1-12.

Cust, Mrs. Henry (i.e. Emmeline Mary Elizabeth, alias Nina). 1928. Wanderers. Episodes from the Travels of Lady Emmeline Stuart-Wortley and Her Daughter Victoria, 1849-1855. Preface by Sir Ronald Storrs. London: Jonathan Cape.

Cust, Mrs. Henry (i.e. Emmeline Mary Elizabeth, alias Nina). 1929. Echoes from Larger Life: A Selection from the Early Correspondence of Victoria Lady Welby, Mrs. Henry Cust (Intro.), 11-13. London: Jonathan Cape.

Cust, Mrs. Henry (i.e. Emmeline Mary Elizabeth, alias Nina). 1931. Other Dimensions. A Selection from the Later Correspondence of Victoria Lady Welby, Lawrence Pearsall Jacks (Intro.), 11-14. London: Jonathan Cape.

Danesi, Marcel \& Thomas A. Sebeok. 2000. The Forms of Meaning. Modeling Systems Theory and Semiotics. Boston/Berlin: De Gruyter Mouton.

Hardwick, Charles S. (ed.). 1977. Semiotic and Significs: The Correspondence Between Charles S. Peirce and Victoria Lady Welby. Bloomington: Indiana University Press.

Darwin, Charles. 1859. The Origin of Species, Gavin de Beer (ed. intro. \& notes). Oxford: Oxford University Press.

Levinas, Emmanuel. 1974. Autrement qu'être ou au-delà de l'essence. The Hague: Martinus Nijhoff.

Levinas, Emmanuel. 2000. Alphonso Lingis (trans.). Otherwise than Being or Beyond Essence. Pittsburgh: Duquesne University Press.

Peirce, Charles Sanders. 1931-1958. Collected Papers of Charles Sanders Peirce (1866-1913), Vols. I-VI, 1931-1935, Charles Hartshorne \& Paul Weiss (eds.), Vols. VII-VIII, 1958, W. Burks (ed.). Cambridge (Mass.): The Belknap Press, Harvard University Press. [In the text referred to as $C P$ followed by volume and paragraph number.]

Petrilli, Susan. 2009. Signifying and Understanding. Reading the Works of Victoria Welby and the Signific Movement. Paul Cobley (Foreword, vii-xiv). Berlin: Mouton.

Petrilli, Susan. 2012. Expression and Interpretation in Language, Vincent Colapietro (Pref.). New Brunswick, NJ/London: Transaction Publishers.

Petrilli, Susan. 2014. Sign Studies and Semioethics. Communication, Translation, and Values. Berlin: Mouton de Gruyter.

Petrilli, Susan. 2015. Victoria Welby and the Science of Signs. Significs, Semiotics, Philosophy of Language, Frank Nuessel (Foreword, xii-xv). Brunswick: Transaction.

Petrilli, Susan \& Augusto Ponzio. 2005. Semiotics Unbounded. Interpretive Routes through the Open Network of Signs. Toronto: Toronto University Press.

Posner, Roland, Klaus Robering \& Thomas A. Sebeok (eds.). 1997-2004. Semiotik/ Semiotics. A Handbook on the Sign-Theoretic Foundations of Nature and Culture, 4 Vols. Berlin: Walter de Gruyter

Sebeok, Thomas A. 1986. I Think I Am a Verb: More Contributions To the Doctrine of Signs. New York/London: Plenum Press.

Sebeok, Thomas A. 1994. Signs. An Introduction to Semiotics. Toronto: Toronto University Press, 2nd edn. 2001.

Sebeok, Thomas A. 2001. Global Semiotics. Bloomington: Indiana University Press.

Stirner, Max. 1972 [1844]. Der Einzige und sein Eigentum. Stuttgart: Reclam-Verlag, 1972; Eng. trans. The Ego and Its Own, David Leopold (ed.). Cambridge/New York: Cambridge University Press. 
Tönnies, Ferdinand. 1899-1900. Philosophical terminology (I, II, III). (Welby Prize Essay, Trans. Mrs. B. Bosanquet.) Mind, 8(31/32), 286-332, 467-491, 9(33), 46-61.

Welby, Victoria. 1852. A Young Traveller's Journal of a Tour in North and South America during the Year 1850 , with numerous illustrations by the authoress engraved by T. Bolton. London: T. Bosworth.

Welby, Victoria. 1881. Links and Clues. London: Macmillan \& Co., $1883^{2}$. A selection of passages is now available in Susan Petrilli 2009, 81-98.

Welby, Victoria. 1886. The ministry of women: A suggested eirenicon. [2 pages]. Grantham: W. Clarke. Now in Susan Petrilli 2009, 118-120.

Welby, Victoria. 1893. Meaning and metaphor. The Monist, 3(4), 510-525. Now in Susan Petrilli 2009, 421-430.

Welby, Victoria. 1896. Sense, meaning and interpretation. Mind, N. S., 5(17), 24-37, 5(18), 186-202. Now in Susan Petrilli 2009, 430-449.

Welby, Victoria. 1897. Grains of Sense. London: J. M. Dent and Co. A selection of passages is now available in Susan Petrilli 2009, 98-111.

Welby, Victoria. 1902a (with G. F. Stout). Sensal. In: J. M. Baldwin 1901-1905, vol. 2, 515. Now in Susan Petrilli 2009, 194-195.

Welby, Victoria. 1902b (with George F. Stout and James M. Baldwin). Significs. In: James M. Baldwin 1901-1905, Vol. 2, 529. Now in Susan Petrilli 2009, 194-195.

Welby, Victoria. 1902c. Translation. In: J. M. Baldwin 1901-1905, Vol. 2, 712. Now in Susan Petrilli 2009, 194-195.

Welby, Victoria. 1903. What Is Meaning? Studies in the Development of Significance. London: Macmillan. New edn. with the addition of writings by others, see Welby 1983.

Welby, Victoria. From Victoria Lady Welby. (Written communication on eugenics: Its definition, scope and aims. By Mr. Francis Galton). Sociological Papers, 1 (1904), 76-78. London: Macmillan. Now in Susan Petrilli 2009.

Welby, Victoria. 1906. From the Hon. Lady Welby. (Written communication on eugenics. By Mr. Francis Galton.) Sociological Papers, 2 (1905), 43-45. London: Macmillan. Now in Susan Petrilli 2009.

Welby, Victoria. 1911a. Significs and Language: The Articulate Form of Our Expressive and Interpretative Resources. London: Macmillan \& Co. Now included with some of her other writings in Welby 1985a.

Welby, Victoria. 1911b. Significs. In Encyclopaedia Britannica, 11th edition, vol. XXV, 78-81. Cambridge: Cambridge University Press. In Charles Hardwick 1977, 167-175. Now in Susan Petrilli 2009, 345-350.

Welby, Victoria. 1983 [1903]. What Is Meaning? Studies in the Development of Significance. Achim Eschbach (ed. \& pref., ix-xxxii), Gerrit Mannoury (intro., xxxiv-xlii) (Foundations of Semiotics 2). Amsterdam/Philadelphia, PA: John Benjamins.

Welby, Victoria. 1985. Significs and Language, H. W. Schmitz (ed. \& Intro.) (Foundations of Semiotics 5). Amsterdam/ Philadelphia, PA: John Benjamins. Includes Welby's monograph of 1911, Significs and Language, and a selection of other writings by her.

Welby, Victoria. 2009. Signifying and Understanding: Reading the Works of Victoria Welby and the Signific Movement, P. Cobley (Pref.). Berlin: Mouton. This monograph by Susan Petrilli includes a vast selection of published $\&$ unpublished writings by Victoria Welby.

Welby Collection at the York University Archives \& Special Collections, Scott Library, York University, Downsview, Toronto, Ontario, Canada. [The Welby Collection presents forty- 
two boxes divided into two main sections: Box 1-21: correspondence, 1861-1912; Box 2242: subject files.] 


\section{Bionote}

\section{Susan Petrilli}

Susan Petrilli (b. 1954) is Professor in Philosophy and Theory of Languages at the University of Bari Aldo Moro, Italy. Her main research interests concern Philosophy of Language and Semiotics. Her most recent books include Challenges to Living Together. Transculturalism, Migration, Exploitation (2017); The Global World and Its Manifold Faces. Otherness at the Basis of Communication (2016); and Victoria Welby and the Science of Signs. Significs, Semiotics, Philosophy of Language (2015). 